\title{
Hubungan antara Kecergasan Fizikal dengan Prestasi Kokurikulum dalam kalangan Murid Sekolah Rendah
}

\section{(The Relationship between Physical Fitness and Co-Curriculum Performance among Primary School Students)}

\author{
Nursuhaila Mohamad Zaini ${ }^{*}$, Tajul Arifin Muhamad² \\ 1Fakulti Pendidikan, Universiti Kebangsaan Malaysia (UKM), 43600, Bangi, Selangor, Malaysia. \\ Email: p105859@siswa.ukm.edu.my \\ ${ }^{2}$ Fakulti Pendidikan, Universiti Kebangsaan Malaysia (UKM), 43600, Bangi, Selangor, Malaysia. \\ Email: tajul.a@ukm.edu.my
}

\section{CORRESPONDING \\ AUTHOR (*):}

Nursuhaila Mohamad Zaini

(p105859@siswa.ukm.edu.my)

KATA KUNCI:

Kecergasan

Fizikal

Prestasi Murid

Sukan

Kokurikulum

Kelab dan Persatuan

\section{KEYWORDS:}

Fitness

Physical

Student Performance

Sports

Co-curriculum

Clubs and Associations

\section{CITATION:}

Nursuhaila Mohamad Zaini, \& Tajul Arifin Muhamad. (2022). Hubungan antara Kecergasan Fizikal dengan Prestasi Kokurikulum dalam kalangan Murid Sekolah Rendah. Malaysian Journal of Social Sciences and Humanities (MJSSH), 7(2), e001269.

https://doi.org/10.47405/mjssh.v7i2.1269

\section{ABSTRAK}

Pendidikan Jasmani di sekolah merupakan satu pendidikan yang menjadi platform utama untuk melihat prestasi murid sekolah rendah mahupun sekolah menengah. Kajian yang dijalankan oleh pengkaji untuk mengenal pasti hubungan kecergasan fizikal dengan prestasi kokurikulum murid tahun 6 di SK Tualak, Kuala Nerang, Kedah. Sampel kajian ini seramai 60 orang murid sekolah rendah. Kaedah pengumpulan data kajian adalah dengan meneliti ujian kecergasan berdasarkan panduan Standard Kecergasan Fizikal Kebangsaan Untuk Murid Sekolah Malaysia (SEGAK). Melalui ujian SEGAK ini, pengkaji melihat penglibatan aktif murid dalam kokurikulum sekolah dan Pendidikan Jasmani. Berdasarkan hasil analisa data ujian (SEGAK) didapati bahawa murid tidak cergas seramai 7 orang (11.7\%), kurang cergas 10 orang $(16.7 \%)$, cergas 36 orang $(60.0 \%)$, kecergasan tinggi 7 orang $(11.7 \%)$ dan kecergasan sangat tinggi 1 orang (1.7\%). Dapatan kajian menunjukkan mereka berada pada tahap sederhana dalam kecergasan fizikal secara keseluruhan. Data analisis bagi prestasi kokurikulum pula menunjukkan prestasi sukan dengan nilai min $M=1.93$, SD .251, unit uniform dengan nilai min $M=2.06$, SD .206, kelab dan persatuan dengan nilai min $M=1.98$, SD.390. Keseluruhan skor pada analisis deskriptif menunjukkan nilai min $M=1.91$, SD .278. Skor yang disenaraikan adalah berada pada tahap rendah. Data analisis kajian bagi hubungan antara kecergasan fizikal mempunyai nilai korelasi pearson $r=0.28 \operatorname{Sig} p=.001$ berada pada tahap rendah. Dapatan kajian mendapati bahawa skor kecergasan sukan dengan prestasi sukan adalah nilai tidak signifikan antara kedua pemboleh ubah yang diuji. Hasil kajian ini menunjukkan bahawa aktiviti kokurikulum yang banyak di sekolah dapat memberi peluang kepada murid melibatkan aktiviti fizikal ini dapat meningkatkan kecergasan fizikal. 


\begin{abstract}
Physical Education in schools is an education that is the main platform to see the performance of primary and secondary school students. A study conducted by researchers to identify the relationship between physical fitness on co curricular performance of year 6 students at SK Tualak. The sample of this study was 60 primary school students. The method of data collection of the study is to examine the fitness test based on the guidelines of the National Physical Fitness Standard for Malaysian School Children (SEGAK). Through this SEGAK test, the researcher saw the active involvement of students in the school co -curriculum and Physical Education. Based on the results of test data analysis (SEGAK) found that students are less active as many as 7 people $(11.7 \%)$, less active 10 people $(16.7 \%)$, active 36 people $(60.0 \%)$, high fitness 7 people $(11.7 \%)$ and very high fitness 1 person (1.7\%). The findings of the study showed that they were at a moderate level in overall physical fitness. Analytical data for co -curricular performance showed sports performance with a mean value of $M=1.93$, SD .251, uniform units with a mean value of $M=2.06$, SD .206 , clubs and associations with a mean value of $\mathrm{M}=1.98, \mathrm{SD} .390$. The overall score on the descriptive analysis showed a mean value of $\mathrm{M}=1.91, \mathrm{SD} .278$. The scores listed are at a low level. The study analysis data for the relationship between physical fitness has a pearson correlation value of $r=0.28$ Sig $p=.001$ is at a low level. The findings of the study found that sports fitness scores with sports performance were insignificant values between the two variables tested. The results of this study show that many co -curricular activities in school can provide opportunities for students to engage in physical activities can improve physical fitness.
\end{abstract}

Sumbangan/Keaslian: Kajian ini adalah satu daripada kajian yang telah mengkaji kecergasan fizikal murid terhadap prestasi kokurikulum. Dapatan kajian ini membantu pemahaman guru, jurulatih dan pihak sekolah semasa merancang aktiviti atau program yang bersesuaian bagi meningkatkan kecergasan murid supaya prestasi kokurikulum meningkat.

\title{
1. Pengenalan
}

Pendidikan Jasmani merupakan suatu proses yang bertujuan meningkatkan prestasi manusia melalui aktiviti fizikal yang berkait rapat dengan pemilikan dan penghalusan kemahiran-kemahiran motor; pembangunan dan pemeliharaan kecergasan untuk kesihatan optimum dan keadaan baik; memperoleh pengetahuan, dan pembangunan sikap-sikap positif terhadap aktiviti fizikal (Ong et al., 2021). Pendidikan Jasmani juga dapat memberi pendidikan melalui aktiviti fizikal dan matlamatnya mempengaruhi semua perkembangan fizikal termasuk perkembangan mental dan sosial (Wan Azlan \& Tajul Ariffin, 2019).

Pendidikan Jasmani amat penting untuk dilaksanakan dalam kurikulum sekolah rendah. Hal ini demikian kerana, melalui pendidikan jasmani, pelbagai aspek dapat dikembangkan ke tahap yang lebih tinggi. Sebagai contoh, aspek JERIS seseorang individu 
mungkin akan terjejas sekiranya mereka mengabaikan aspek pembangunan fizikal dan jasmani diri masing-masing. Hasrat di dalam Falsafah Pendidikan Negara yang bertujuan untuk melahirkan insan yang seimbang dari segi intelek, rohani, emosi, jasmani dan sosial (JERIS) maka peranan yang sangat besar perlu dimainkan oleh seorang guru dalam merealisasikan hasrat yang terkandung dalam falsafah pendidikan tersebut (Saharia, 2015). Falsafah Pendidikan Kebangsaan (FPK) penting dalam pelaksanaan pendidikan negara. FPK menjadi panduan kepada semua pihak untuk memastikan penterjemahannya dapat mencapai hasrat pendidikan negara untuk melahirkan warga negara yang cemerlang dan cergas.

Pendidikan di Malaysia adalah satu usaha berterusan ke arah memperkembangkan lagi potensi individu secara menyeluruh dan bersepadu untuk mewujudkan insan yang seimbang dan harmonis dari segi intelek, rohani, emosi dan jasmani. Sejajar dengan aspirasi yang disuratkan oleh Falsafah Pendidikan Kebangsaan, tunjang fizikal dan estetika merupakan tunjang yang mendukung hasratkan iaitu untuk melahirkan insan yang seimbang dari segi jasmani, emosi, rohani dan intelek. Kesihatan jasmani murid menjamin pembangunan potensi murid dalam domain yang lain. Perkembangan jasmani dan kesihatan murid harus selari dengan keperluan fizikal dan peringkat umur dan tahap kematangan murid. Bidang pembelajaran yang berkaitan ilmu Pendidikan Jasmani dan Kesihatan merupakan teras ilmu dalam menterjemahkan hasrat tunjang ini. Selain daripada aspek fizikal, potensi estetika murid juga perlu diberi penekanan.

\begin{abstract}
"Pendidikan di Malaysia adalah suatu usaha berterusan ke arah lebih memperkembangkan potensi individu secara menyeluruh dan bersepadu untuk melahirkan insan yang seimbang dan harmonis dari segi intelek, rohani, emosi, dan jasmani, berdasarkan kepercayaan dan kepatuhan kepada Tuhan. Usaha ini adalah bertujuan untuk melahirkan warganegara Malaysia yang berilmu pengetahuan, berketerampilan, berakhlak mulia, bertanggungjawab, dan berkeupayaan mencapai kesejahteraan diri serta memberikan sumbangan terhadap keharmonian dan kemakmuran keluarga, masyarakat, dan negara"

Sumber: Akta Pendidikan 1996 (Akta 550)
\end{abstract}

Menurut Corbin dan Lindsey (2006), kecergasan adalah keupayaan sistem badan bekerja dengan efisien bagi membolehkan seseorang itu sihat dan dapat melaksanakan aktiviti dalam kehidupan seharian. Komponen Kecergasan berdasarkan kesihatan terdiri daripada daya tahan kardiovaskular, daya tahan otot, kekuatan otot, fleksibiliti, dan komposisi badan. Tahap kecergasan berdasarkan kesihatan yang tinggi memberi faedah kepada seseorang itu memiliki kesihatan yang baik, bertenaga, dan mempunyai keupayaan untuk melakukan aktiviti harian dengan berkesan. Kecergasan fizikal yang optimum boleh membantu seseorang murid itu melaksanakan aktiviti harian dengan aktif tanpa berasa letih. Selaras dengan itu, satu aktiviti kecergasan yang terancang di sekolah perlu dilaksanakan dengan sempurna mengikut prosedur dan norma yang ditetapkan.

\title{
2. Permasalahan Kajian
}

Transformasi dan masalah pembangunan sukan sekolah kerap dibincangkan oleh pelbagai pihak terutamanya media yang menyatakan isu kepimpinan organisasi dan sukan dalam membangunkan kecemerlangan sekolah dan sukan Malaysia. Terdapat Persatuan Sukan Kebangsaan (NSA) yang memperdebatkan isu kepada KPM dalam mengusahakan pembangunan Sukan. Kementerian Pendidikan Malaysia (KPM) 
memainkan peranan penting dalam menyokong kecemerlangan sekolah. Pihak kerajaan juga banyak melaburkan modal dalam bentuk kewangan bagi memenuhi keperluan sukan dan tanggungjawab.

Hasrat kerajaan dalam Pelan Pembangunan Pendidikan Malaysia 2013-2025 (PPPM 2013-2025) agar potensi murid dapat diasah dengan potensi murid dan diperkembangkan lagi dengan potensi akademi dalam pelbagai aspek yang sewajarnya. Kecemerlangan akademik juga bukan sahaja penting namun pencapaiannya perlu di isi dengan pembinaan sahsiah peribadi murid yang berdaya saing agar potensi mereka dapat diasah dan digilap dalam kesukanan (Md Suhaimi et al., 2018). Hal ini demikian kerana, wajar diakui melalui menyemai nilai sahsiah diri perlu dibentuk dengan kegiatan sukan, agar murid boleh mengisi masa dengan sesuatu perkara yang bermanfaat, baik untuk kesihatan.

Kokurikulum perlu dihasilkan secara positif dan membentuk keupayaan kendiri yang membentuk aspirasi dan mengurangkan masalah sosial. Penglibatan murid dalam aktiviti kokurikulum membuka ruang kepada murid memperkembangkan bakat dan kepentingan murid di luar bilik darjah. Pelbagai aktiviti dan sumber ruang boleh membentuk kepentingan kokurikulum dan bahan yang sesuai untuk membangunkan pelajar yang aktif dan mempunyai pemikiran yang luar biasa (Mohammad Sari \& Esa, 2015). Kepentingan Dasar 1 Murid 1Sukan (1M1S) telah dilaksanakan oleh guru dalam dasar kokurikulum perlu diselarikan agar tidak terbeban kerja guru. Oleh itu, KPM perlu menyediakan pelbagai inisiatif latihan yang efektif bagi memenuhi dasar pendidikan oleh para guru.

\section{Objektif Kajian}

Objektif kajian ini adalah untuk:

i. Mengenal pasti tahap kecergasan murid tahun 6 di SK Tualak, Kuala Nerang, Kedah.

ii. Mengenal pasti tahap pencapaian PAJSK murid tahun 6 SK Tualak, Kuala Nerang, Kedah.

iii. Mengenal pasti hubungan kecergasan fizikal dengan prestasi kecergasan murid tahun 6 di SK Tualak, Kuala Nerang, Kedah.

\section{Persoalan Kajian}

Kajian ini menjawab kepada soalan-soalan kajian seperti yang berikut:

i. $\quad$ Apakah tahap kecergasan murid tahun 6 di SK Tualak?

ii. Apakah tahap pencapaian PAJSK murid tahun 6 SK Tualak?

iii. Adakah terdapat perkaitan yang signifikan antara prestasi kecergasan dengan prestasi kokurikulum?

\section{Sorotan Literatur}

\subsection{Kecergasan Fizikal}

Standard kurikulum ini juga memberi penekanan kepada penerapan nilai murni dalam membentuk insan yang sempurna dan berkembang secara menyeluruh daripada aspek jasmani, emosi, rohani, intelek dan sosial melalui pengajaran secara teori dan amali. Pengajaran dan pembelajaran yang dijalankan dalam suasana yang kondusif perlu untuk 
membantu merangsang dan meningkatkan kreativiti dan minat murid untuk belajar dengan berkesan. Standard kandungan ini mengutamakan pendemokrasian pendidikan kepada semua murid sekolah rendah ke arah merealisasikan hasrat Falsafah Pendidikan Kebangsaan. Jelaslah bahawa Pendidikan Jasmani dan Kesihatan itu penting kerana merupakan salah satu mata pelajaran yang dimuatkan di sekolah yang mampu untuk memenuhi aspek pengajaran menyeluruh dari segi teori dan amali.

Selain daripada itu, dengan penambahan lemak dalam badan dan kemerosotan kekuatan otot boleh menjejaskan postur badan dan akan menyebabkan masalah fizikal seperti kecacatan ortopedik. Oleh itu, kesihatan fizikal manusia perlu ditambah baik dengan aktiviti yang boleh meningkatkan fungsi masing-masing. Menurut WHO (2010), saranan kekerapan melakukan aktiviti fizikal boleh dibahagikan kepada tiga kategori kumpulan umur. Kategori umur yang pertama bermula seawal 5 tahun sehingga 17 tahun. Kategori umur yang kedua bermula pada 18 tahun hingga 64 tahun dan yang terakhir berusia 65 tahun dan ke atas. Saranan aktiviti fizikal bagi Umur 5 hingga 17 tahun perlu dilakukan sekurang-kurangnya 60 minit sama ada dalam aktiviti fizikal tahap sederhana atau tahap tinggi setiap hari. Tempoh yang lebih dari 60 minit akan memberikan lebih banyak faedah pada kesihatan. Saranan aktiviti fizikal bagi Umur 18 Tahun hingga 64 Tahun pula, individu ini perlu melakukan sekurang-kurangnya 150 minit aktiviti fizikal berintensiti sederhana sepanjang minggu atau sekurang kurangnya 75 minit aktiviti fizikal yang berintensiti tinggi.

Peningkatan terhadap kehidupan yang berkualiti dan amalan gaya hidup cara sihat merupakan konsep yang perlu diterapkan dalam dunia moden masa kini. Kesedaran untuk membina perspektif individu yang sihat dan cergas adalah gagasan yang melibatkan kecergasan secara keseluruhan. Kecergasan keseluruhan adalah integrasi komponen mental, sosial, emosi, fizikal, intelektual dan rohani (Corbin et al., 2002). Memiliki kecergasan yang seimbang membolehkan individu memberikan sumbangan yang bermakna kepada diri, keluarga, masyarakat dan negara. Kecergasan keseluruhan ini dapat mencerminkan perasaan seseorang individu tentang kehidupan serta keupayaan diri untuk berfungsi dengan lebih cekap dan berkesan. Kecergasan merupakan keupayaan dan kemampuan seseorang melakukan sesuatu dengan sempurna. Kecergasan meliputi aspek fisiologikal, psikologikal, dan sosiologikal. Kecergasan keseluruhan (total fitness) boleh digambarkan sebagai keupayaan menjalani kehidupan yang sempurna dan keupayaan memberikan sumbangan dan perkhidmatan yang terbaik. Integrasi komponen kecergasan keseluruhan tersebut adalah penting, keseimbangan kecergasan ini saling memenuhi antara satu sama lain bagi tujuan melahirkan individu yang sihat dan cergas.

Kecergasan fizikal boleh dibahagikan kepada dua komponen utama iaitu berasaskan kesihatan dan berasaskan perlakuan motor. Kecergasan fizikal berlandaskan kesihatan merujuk kepada kekuatan otot, daya tahan kardiovaskular, komposisi badan, kelenturan, dan daya tahan otot. Manakala kecergasan berlandaskan perlakuan motor merujuk kepada kelajuan, ketangkasan, kuasa otot, imbangan, koordinasi, dan masa tindak balas. Kecergasan yang optimum boleh membantu murid dalam melaksanakan aktiviti harian dengan cekap dan berkesan tanpa berasa letih.

Menurut Khedri, Chan dan Helen (2015), kecergasan fizikal acap kali dikaitkan dengan keupayaan seseorang individu menggunakan masa senggang mereka, bagaimana mereka menentang penyakit hipokinetik dan bagaimana mereka menghadapi kecergasan tersebut. Peningkatan kepada sesuatu set aktiviti kecergasan dirancang dan dilaksanakan 
untuk membantu pelajar mendapatkan keputusan kecergasan yang optimum mengikut prosedur serta norma yang telah ditetapkan.

Oleh itu, satu penilaian piawai dikenali sebagai Program Penilaian Standard Kecergasan Fizikal Kebangsaan Untuk Murid Sekolah Malaysia (SEGAK) diperkenalkan. Program ini dirancang ada tahun 2005 dan telah dirangka untuk dilaksanakan mulai sesi persekolahan pada setiap tahun. Walau bagaimanapun, ia mula dilaksanakan pada tahun 2008. Program penilaian SEGAK ini dirancang selari dengan tunjang kecergasan yang terkandung dalam Sukatan Pelajaran Pendidikan Jasmani dan Pendidikan Kesihatan Sekolah Rendah dan Menengah. Pelaporan hasil SEGAK akan menjadi komponen kecergasan kepada penilaian berasaskan sekolah. Komponen kecergasan yang diuji dalam SEGAK adalah komponen kecergasan fizikal berasaskan kesihatan iaitu Indeks Jisim Badan (BMI), kekuatan otot, daya tahan otot, kelenturan badan dan daya tahan kardiovaskular

Selain itu, pergaulan yang baik dapat wujud ketika melakukan aktiviti lebih-lebih lagi yang memerlukan penglibatan di dalam pasukan. Disamping itu,nilai kerjasama juga dapat diwujudkan. Pendidikan fizikal ini juga merupakan sebahagian daripada proses pendidikan yang memberi fokus terhadap pembelajaran fizikal, intelektual, sosial dan emosi melalui pengalaman aktiviti fizikal (Doherty \& Brennan, 2007).

\subsection{Prestasi Kokurikulum}

PAJSK merupakan salah satu pentaksiran yang terdapat dalam Pentaksiran Berasaskan Sekolah. PAJSK mempunyai lima komponen yang perlu ditafsirkan oleh guru pendidikan jasmani, guru-guru penasihat unit beruniform, kelab atau persatuan dan sukan atau permainan (1M1S). Antara komponen PAJSK ialah Standard Kecergasan Fizikal Kebangsaan (SEGAK), Body Mass Index (BMI), sukan, kokurikulum dan ekstra kurikulum. PAJSK adalah sebagai panduan untuk menilai aktiviti fizikal dan kesihatan serta mengukur penyertaan jasmani, sukan, kokurikulum dan ekstra kurikulum (Zulkifli \& Norazilawati, 2016).

Sistem persekolahan di Malaysia, sukan adalah bidang kokurikulum yang dikenali dan dibuat pecahan asas kokurikulum itu. Surat Pekeliling Ikhtisas Bil. 1/1985 bertarikh 2 Januari 1985 yang telah dikeluarkan oleh kementerian pelajaran telah memberi penekanan kepada penglibatan murid dalam kokurikulum. Bidang sukan adalah penting untuk meningkatkan keupayaan fizikal murid, mencergaskan minda dan tubuh badan yang sihat. Selain itu, pembangunan sukan dapat melahirkan insan yang produktif, cergas, sihat dan memberikan sumbangan kepada kesejahteraan sosial demi pembangunan ekonomi. Kesejahteraan murid terletak kepada kemampuan dan keupayaan dalam mengoptimumkan peluang yang diberikan dan sokongan yang sedia ada. Gaya hidup sihat dan aktif akan dapat menarik minat murid dalam pelbagai aktiviti sukan. Keperluan akademik yang seiring dengan kesukanan dalam melahirkan generasi yang menjadi harapan dalam satu dasar yang dilaksanakan oleh KPM.

Gaya hidup yang sihat perlu dididik dari awal dengan penglibatan mata pelajaran PJK di sekolah dengan aktiviti rekreasi, bersosial dan bersukan serta menjaga kesihatan. Kesejahteraan dan pembangunan diri adalah penyumbang kepada pengaruh sikap, pengetahuan, kecerdasan dalam diri seseorang (Wuest \& Bucher, 2001). Murid merupakan seorang yang mudah belajar dan mampu berjaya jika diberi ruang untuk membentuk sikap. Namun begitu, kanak-kanak perlu menguasai dan mengikuti latihan 
daripada jurulatih yang profesional bagi mencipta kejayaan. Latihan yang mencukupi mampu mencapai kejayaan individu dalam sesuatu bidang. Selain dorongan untuk menyertai aktiviti aerobik seperti berjoging atau berenang, pelajar perlu mengambil bahagian dalam latihan ketahanan atau dikenali sebagai latihan kekuatan (Faigenbaum \& Mediate, 2005).

Berdasarkan Peraturan-Peraturan Pendidikan (Persatuan Sekolah) (1998), pihak sekolah boleh menubuhkan sesuatu kegiatan berdasarkan mata pelajaran yang diajar di sekolah sebagaimana yang dinyatakan dalam Peraturan-peraturan Pendidikan (Kurikulum Kebangsaan). Kegiatan juga boleh ditubuhkan daripada kategori hobi dan rekreasi, sukan dan permainan, badan beruniform atau apa-apa kegiatan lain yang diluluskan oleh pendaftar. Kepelbagaian dalam penubuhan kegiatan ini adalah bertujuan untuk memberi peluang kepada murid menyertai kegiatan kokurikulum yang diminatinya (Manchelah, 2017). Kegiatan kokurikulum boleh dijalankan di dalam atau di luar bilik darjah, mengikut kesesuaian sesuatu aktiviti. Di bawah rancangan kokurikulum, tumpuan diberi kepada aktiviti yang merangkumi aspek khidmat masyarakat, rekreasi dan pengayaan di mana kurikulum formal dan pengalaman amali dikukuhkan dan serta diluaskan (Nor Suhara \& Jamil Ahmad, 2010)

Guru pendidikan jasmani harus menambahkan elemen kecergasan untuk sukan berpasukan apabila mungkin dan atau mengubah peraturan untuk mendorong lebih banyak pergerakan (Hill et al., 1992). Guru perlu menyedari trend kecergasan terkini untuk mengembangkan program yang menggabungkan pembelajaran konsep kemahiran dan kecergasan sambil memaksimumkan tahap aktiviti untuk semua pelajar (Chen, Lambert \& Guidry, 2020).

Kajian yang dijalankan oleh Azrina et al . (2017), membincangkan tentang pelajar pintar dan berbakat adalah satu aset kepada negara. Penekanan akademik yang diberikan mungkin berbeza dengan pelajar biasa. Walau bagaimanapun kecergasan fizikal juga memainkan peranan dalam perkembangan kognitif pelajar. Kajian ini bertujuan untuk melihat tahap kecergasan pelajar pintar dan berbakat dan melihat hubungannya dengan pencapaian markah dalam sesuatu mata pelajaran. Kajian Liza et al. (2020), mengkaji aktiviti fizikal dan kecergasan mempengaruhi tahap kesihatan murid. Tujuan kajian ini adalah untuk mengkaji corak aktiviti fizikal dan tahap kecergasan murid sekolah menengah rendah. Sampel kajian terdiri daripada 128 orang murid tingkatan 1 di kawasan Tangga Batu, Melaka yang terdiri daripada 55 orang murid lelaki dan 73 orang murid perempuan. Reka bentuk kajian adalah berbentuk tinjauan iaitu melalui borang soal selidik dan ujian kecergasan fizikal. Kajian ini menggunakan Physical Activity Questionnaire for Children (PAQ-C) dan ujian Standard Kecergasan Fizikal Kebangsaan Untuk Murid Sekolah Malaysia (SEGAK).

Selain itu, kajian oleh Mohd Tarmizi dan Mohd Radzani (2019) mengkaji kajian bagi mengenal pasti sumbangan aktiviti kokurikulum dan Pendidikan Jasmani terhadap kecergasan fizikal pelajar sekolah rendah. Sampel kajian beliau terdiri daripada 40 orang pelajar sekolah rendah. Kaedah kajian ini adalah dengan menjalankan beberapa jenis ujian kecergasan berdasarkan panduan Standard Kecergasan Fizikal Kebangsaan Untuk Murid Sekolah Malaysia (SEGAK). Terdapat lima set ujian (SEGAK) ini, iaitu Pengiraan Indeks Jisim Badan, Ujian Naik Turun Bangku selama tiga minit, Ujian Tekan Tubi, Ujian Ringkuk Tubi Separa, dan Ujian Jangkauan Melunjur. Selain itu, soal selidik menggunakan Global Physical Activity Questionnaire (GPAQ) akan diedarkan kepada pelajar untuk mendapatkan data mengenai aktiviti kokurikulum dan Pendidikan Jasmani. 
Kegiatan kokurikulum di peringkat sekolah dibahagikan kepada tiga jenis iaitu pasukan pakaian seragam atau unit beruniform, persatuan atau kelab serta sukan dan permainan, seperti yang diringkaskan dalam Rajah 1 di bawah.

Rajah 1: Komponen kokurikulum

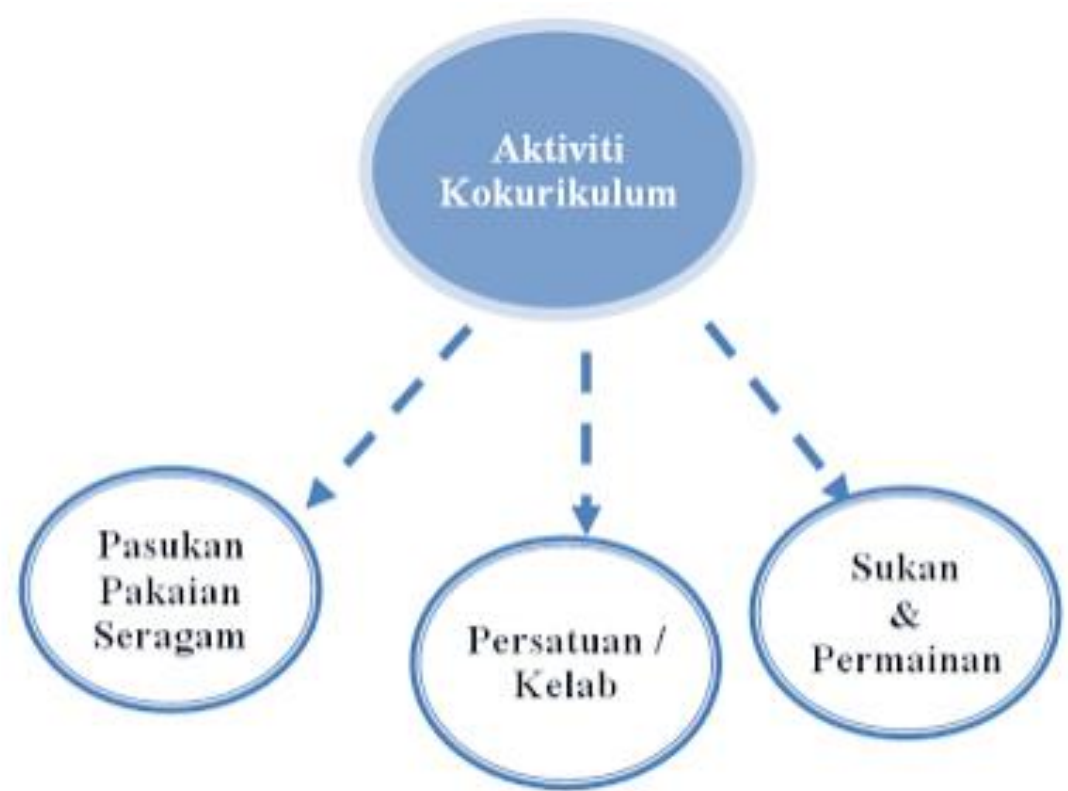

Sumber: Mok (2008)

\section{Metod Kajian}

Kajian ini menggunakan reka bentuk penyelidikan deskriptif kolerasi untuk murid tahun 6 SK Tualak terhadap kecergasan fizikal. Chua (2011) menyatakan penyelidikan deskriptif dapat menggambarkan profil, peristiwa atau situasi dalam sesebuah kajian dan sangat penting dalam menentukan kaedah metodologi yang akan digunakan untuk membantu dalam proses analisis kajian. Reka bentuk ini menawarkan kepada para penyelidik profil aspek-aspek yang berkaitan dengan fenomena yang dijelaskan dari perspektif individu, organisasi, dan industri. Kajian ini mengaplikasikan kaedah persampelan bertujuan untuk memilih peserta yang dapat memberi data yang kaya dengan deskripsi untuk menerangkan fenomena yang dikaji. Menurut kajian Sekaran dan Bougie (2013) populasi merujuk kepada kumpulan individu yang lengkap (subjek atau peristiwa).

\subsection{Responden}

Pemilihan respon kajian ini ditentukan dengan menggunakan kaedah persampelan bertujuan. Kajian ini melibatkan 60 orang murid tahun 6 di Sekolah Kebangsaan Tualak, Kuala Nerang, Kedah. Seramai 28 orang murid lelaki dan 32 orang murid perempuan.

\subsection{Instrumen}

Instrumen yang digunakan dalam kajian ini ialah borang soal selidik. Ujian Standard Kecergasan Fizikal Kebangsaan untuk murid sekolah Malaysia (SEGAK) digunakan untuk mengukur tahap kecergasan murid tahun 6 SK Tualak. Manakala Pentaksiran Aktiviti Jasmani, Sukan dan Kokurikulum (PAJSK) digunakan untuk melihat tahap pencapaian 
kokurikulum murid tahun 6 SK Tualak. Soal selidik menggunakan SEGAK sebagai ujian kecergasan fizikal menguji lima ujian iaitu Indeks Jisim Tubuh (IJT), turun naik bangku 3 minit, tekan tubi, ringkuk tubi separa, dan jangkauan melunjur. Tujuan bateri ujian ini dilakukan adalah untuk mengukur daya tahan kardiovaskular, daya tahan otot, kekuatan otot, dan kelenturan tubuh. Bagi menganalisis data tahap kecergasan murid dan prestasi ditentukan dengan interpretasi Wiersma (1995) seperti yang ditunjukkan dalam Jadual 1.

Jadual 1: Interpretasi min skor

\begin{tabular}{ll}
\hline Skor Min & Interpretasi \\
\hline $1.00-2.33$ & Tidak Cergas / Tidak Aktif / Berintensiti Rendah \\
$2.34-3.67$ & Sederhana Cergas / Sederhana Aktif / Berintensiti Sederhana \\
$3.68-5.00$ & Cergas / Aktif / Berintensiti Tinggi \\
\hline
\end{tabular}

Sumber: Wiersma (1995)

\section{Hasil Kajian}

\subsection{Profil Responden}

Demografi pertama yang ditinjau adalah jantina responden kajian. Sampel kajian ini adalah seramai 60 orang responden yang terdiri daripada lelaki dan perempuan. Dapatan kajian menunjukkan responden lelaki seramai 28 orang $(46.7 \%)$ dan perempuan 32 (53.3\%). Demografi kedua, kecergasan sukan murid. Kecergasan sukan murid terdiri daripada 4 kategori iaitu tidak cergas, kurang cergas, cergas, dan kecergasan tinggi. Dapatan kajian menunjukkan bahawa murid tidak cergas seramai 7 orang $(11.7 \%)$, kurang cergas 25 orang (41.7\%), cergas 21 orang (35.0\%) dan kecergasan tinggi 7 orang (11.7\%). Demografi ketiga menunjukkan tahap pencapaian/peringkat pencapaian murid dalam kesukanan dan kurikulum di sekolah. Terdapat 3 kategori sekolah, daerah dan negeri. Pencapaian daerah seramai 11 orang (18.3\%), negeri 2 orang (3.3\%) dan sekolah 47 orang $(78.3 \%)$.

\subsection{Tahap Kecergasan Murid}

Tahap Kecergasan Sukan mempunyai 4 kategori yang menjadi ukuran kepada tahap kecergasan murid iaitu tidak cergas, kurang cergas, cergas dan kecergasan tinggi. Dapatan kajian menunjukkan bahawa tahap skor kecergasan murid berada pada tahap yang sederhana dengan mempunyai nilai $\min \mathrm{M}=3.35, \mathrm{SD}=.971$ bagi tahap keseluruhan kecergasan murid (Jadual 2).

Jadual 2: Tahap Kecergasan Murid

\begin{tabular}{ccccc}
\hline Pemboleh Ubah & N & Min & SD & Tahap \\
\hline Kecergasan Murid & 60 & 3.35 & .971 & Sederhana \\
\hline
\end{tabular}

Dapatan kajian di Jadual 3 menunjukkan bahawa murid tidak cergas seramai 7 orang (11.7\%), kurang cergas 10 orang (16.7\%), cergas 36 orang (60.0\%), kecergasan tinggi 7 orang (11.7\%) dan kecergasan sangat tinggi 1 orang (1.7\%) (Jadual 3). 
Jadual 3: Skor Kecergasan Murid

\begin{tabular}{cccc}
\hline Markah & Kecergasan & Bilangan (N) & Peratusan (\%) \\
\hline 4-7 Markah & Tidak Cergas & 7 & $11.7 \%$ \\
8-11 Markah & Kurang Cergas & 10 & $16.7 \%$ \\
12-14 Markah & Cergas & 36 & $60.0 \%$ \\
15-17 Markah & Kecergasan Tinggi & 7 & 11.7 \\
18-20 Markah & Kecergasan Sangat & 1 & $1.7 \%$ \\
& Tinggi & & \\
\hline & Jumlah & 60 & $100 \%$ \\
\hline
\end{tabular}

Taburan skor yang terdiri daripada sukan, unit uniform, kelab dan persatuan dan keseluruhan. Dapatan kajian di Jadual 4 menunjukkan skor sukan dengan nilai min $\mathrm{M}=1.93$, SD .251, unit uniform dengan nilai min $\mathrm{M}=2.06$, SD .206, kelab dan persatuan dengan nilai min $\mathrm{M}=1.98$, SD.390 (Jadual 4). Keseluruhan skor pada analisis deskriptif menunjukkan nilai min $\mathrm{M}=1.91$, SD .278. Skor yang disenaraikan adalah berada pada tahap rendah.

Jadual 4: Taburan Skor Prestasi Kokurikulum Murid

\begin{tabular}{lllll}
\hline Skor & Bilangan (N) & Min & SD & Tahap \\
\hline Sukan & 60 & 1.93 & .251 & Rendah \\
Unit Uniform & 60 & 2.06 & .516 & Rendah \\
Kelab dan Persatuan & 60 & 1.98 & .3 .90 & Rendah \\
Keseluruhan & 60 & 1.91 & .278 & Rendah \\
\hline
\end{tabular}

Hasil kajian di Jadual 5 menunjukkan bahawa murid berkebolehan cemerlang dan kepujian sahaja. Dapatan menunjukkan murid mendapat skor 100-80 (cemerlang) seramai 4 orang (4.7\%) dan skor 79.9-80 (kepujian) dengan bilangan 56 orang (93.3\%) (Jadual 5). Skor sukan murid mempunyai nilai min $\mathrm{M}=1.99$, SD.251 dengan tahap yang rendah.

Jadual 5: Prestasi Sukan

\begin{tabular}{lll}
\hline Skor & Bilangan (N) & Peratusan (\%) \\
\hline 100-80 Cemerlang & 4 & $4.7 \%$ \\
79.9-60-Kepujian & 56 & $93.3 \%$ \\
59.9-40- Baik & 0 & 0 \\
39.9-20 Kurang Memuaskan & 0 & 0 \\
19.9-0- Tidak Memuaskan & 0 & 0 \\
\hline
\end{tabular}

Dapatan kajian Jadual 6 menunjukkan bahawa murid berkebolehan terlibat dalam aktiviti unit beruniform cemerlang, kepujian dan baik sahaja. Dapatan menunjukkan murid mendapat skor 10080 (cemerlang) seramai 6 orang (10.0\%), skor 79.9-80 (kepujian) dengan bilangan 44 orang (73.3\%) dan skor 59.9 -40 (baik) seramai 10 orang (16.7\%). Skor unit beruniform murid mempunyai nilai min $\mathrm{M}=2.06$, SD.516 dengan tahap yang rendah. 
Jadual 6: Prestasi Unit Beruniform

\begin{tabular}{lll}
\hline Skor & Bilangan (N) & Peratusan (\%) \\
\hline 100-80 Cemerlang & 6 & $10.0 \%$ \\
79.9-60-Kepujian & 44 & $73.3 \%$ \\
59.9-40- Baik & 10 & $16.7 \%$ \\
39.9-20 Kurang Memuaskan & 0 & 0 \\
19.9-0- Tidak Memuaskan & 0 & 0 \\
\hline
\end{tabular}

Jadual 7 menunjukkan bahawa murid berkebolehan terlibat dalam aktiviti kelab dan Persatuan mempunyai skor cemerlang, kepujian dan baik sahaja. Dapatan menunjukkan murid mendapat skor 100-80 (cemerlang) seramai 5 orang (8.3\%), skor 79.9-80 (kepujian) dengan bilangan 51 orang (85.5\%) dan skor 59.9 -40 (baik) seramai 4 orang (6.7\%). Skor kelab dan persatuan murid mempunyai nilai min $M=2.06$, SD.516 dengan tahap yang rendah.

Jadual 7: Prestasi Kelab dan Persatuan

\begin{tabular}{lcc}
\hline \multicolumn{1}{c}{ Skor } & Bilangan (N) & Peratusan (\%) \\
\hline 100-80 Cemerlang & 5 & $8.3 \%$ \\
79.9-60-Kepujian & 51 & $85.0 \%$ \\
59.9-40- Baik & 4 & $6.7 \%$ \\
39.9-20 Kurang Memuaskan & 0 & 0 \\
19.9-0- Tidak Memuaskan & 0 & 0 \\
\hline
\end{tabular}

\subsection{Hubungan antara Kecergasan Murid dengan Prestasi Sukan}

Berdasarkan Jadual 8, didapati keputusan pekali kolerasi menunjukkan bahawa nilai =.0 .00 dan $\mathrm{p}=.000$. Dapatan menunjukkan bahawa hubungan antara skor kecergasan sukan dengan prestasi sukan mempunyai nilai korelasi pearson $r=0.28$ Sig $p=.001$. Dapatan kajian mendapati bahawa skor kecergasan sukan dengan prestasi sukan adalah nilai tidak signifikan antara kedua pemboleh ubah yang diuji dan menunjukkan hubungan yang rendah.

Jadual 8: Hubungan antara prestasi sukan murid dengan Prestasi Sukan

\begin{tabular}{lll}
\hline Pemboleh ubah & R & Sig (2 tailed) \\
\hline Skor Kecergasan Sukan & .028 & 0.01 \\
Prestasi Sukan & 0.01 & .028 \\
\hline
\end{tabular}

\subsection{Ujian Anova dalam Skor Kecergasan dengan skor keseluruhan murid}

Berdasarkan Jadual 9, didapati terdapat perbezaan yang signifikan skor min tahap skor kecergasan murid berdasarkan adalah ( $\mathrm{F}=5.225$; $\mathrm{p}<0.05)$, sig .001. Dapatan kajian Jadual 10 mendapati bahawa skor sukan murid menunjukkan nilai $(F=.247 ; \mathrm{p}<.940)$, skor uniform menunjukkan nilai ( $\mathrm{F}=2.489$, Sig .042), dan skor kelab pula menunjukkan $(\mathrm{F}=$ 2.057, Sig .085). Walau bagaimanapun, skor min antara skor kecergasan dengan sukan, uniform dan kelab menunjukkan nilai yang signifikan. Walaupun keputusan ujian Anova Sehala tersebut adalah signifikan secara statistik, perbezaan sebenar dalam skor min antara kumpulan agak kecil. Kesan saiz yang dikira menggunakan Eta kuasa dua adalah 0.853 . 
Jadual 9: Ujian Anova dalam Skor Kecergasan dengan Skor Keseluruhan Murid

\begin{tabular}{llll}
\hline Skor & Bilangan $(\mathbf{N})$ & Skor Min & Sisihan Piawai \\
\hline Skor Sukan & 60 & 1.93 & .251 \\
Skor Uniform & 60 & 2.066 & .516 \\
Skor Kelab & 60 & 1.98 & .390 \\
\hline
\end{tabular}

Jadual 10: Skor Darjah Kebebasan

\begin{tabular}{llllll}
\hline Skor & Jumlah Kuasa Dua & Darjah Kebebasan & Min & Nilai F & Signifikan \\
\hline $\begin{array}{l}\text { Antara } \\
\text { Kumpulan }\end{array}$ & .083 & 5 & .017 & .247 & .940 \\
$\begin{array}{l}\text { Dalam } \\
\text { Kumpulan }\end{array}$ & 3.65 & 57 & & & \\
\hline
\end{tabular}

\section{Kesimpulan}

Dapatan kajian ini menunjukkan bahawa tahap kecergasan murid berada pada tahap sederhana manakala prestasi kokurikulum murid secara keseluruhannya adalah berada pada tahap rendah. Hubungan antara kecergasan murid dengan prestasi sukan pula menunjukkan berada pada tahap rendah. Majoriti murid di sekolah ini berada pada tahap sederhana dengan jumlah 36 orang dalam kategori cergas. Kajian ini disokong oleh kajian Azrina et al. (2017) mengkaji tahap kecergasan pelajar pintar dan berbakat dan melihat hubungannya dengan pencapaian markah dalam sesuatu mata pelajaran pelajar mendapati bahawa tahap kecergasan pelajar pintar adalah pada tahap cergas. Analisis juga mendapati terdapat perbezaan yang signifikan tahap kecergasan fizikal pelajar antara jantina dan juga terdapat perbezaan yang signifikan diantara tahap kecergasan fizikal pelajar dengan markah mata pelajaran biologi akhir tahun pelajar pintar dan berbakat.

Liza et al. (2020) membuktikan bahawa kekerapan murid melakukan aktiviti fizikal dalam hari menunjukkan murid kerap melakukan aktiviti fizikal pada hari Sabtu bagi lelaki dan hari Ahad bagi perempuan kerana faktor ibu bapa yang memberikan sokongan bagi membolehkan mereka melakukan aktiviti fizikal seperti di padang awam Dataran Klebang. Tahap kecergasan murid adalah berada pada tahap cergas iaitu 28 orang bagi lelaki dan 35 orang bagi perempuan. Hubungan antara Indeks Jisim Tubuh (IJT) dengan tahap kecergasan menunjukkan terdapat hubungan yang signifikan iaitu nilai sig=.016, $\mathrm{p}$ 0.00 .

Selain itu, dapatan kajian Mohd Tarmizi dan Mohd Radzani (2019) mendapati bahawa hasil analisa data ujian (SEGAK) didapati bahawa $10.00 \%$ responden adalah sangat cergas, $27.50 \%$ adalah cergas, $37.50 \%$ adalah sederhana cergas, $22.50 \%$ adalah kurang cergas, dan $2.50 \%$ adalah tidak cergas. Data analisis juga menunjukkan tahap kecergasan fizikal adalah bergantung kepada keterlibatan seseorang dalam aktiviti vigorousintensity, moderate- intensity dan low intensity pada kadar masa yang tertentu.

Pendidikan Jasmani dan Kesihatan memberi peluang kepada murid-murid untuk meneroka dan bebas bergerak serta melakukan aktiviti mengikut kreativiti mereka tersendiri berdasarkan saranan dan teori yang disampaikan oleh guru-guru sebelum mereka memulakan aktiviti. Murid-murid di sekolah rendah sudah semestinya lebih berminat dan tertarik dengan subjek Pendidikan Jasmani dan Kesihatan kerana mereka 
mampu bergerak tanpa perlu duduk lama di atas kerusi dan menghadap buku yang secara fitrahnya bukan minat mereka yang sedang membesar.

Terdapat banyak faktor yang mempengaruhi tahap penglibatan murid dalam melakukan aktiviti fizikal. Dalam kajian ini mendapati bahawa faktor penghalang untuk melakukan aktiviti fizikal adalah tahap kesihatan yang tidak memberangsangkan, ibu bapa, peperiksaan, dan persekitaran. Selain itu, minat, rakan sebaya dan kemudahan peralatan mempengaruhi penglibatan (Cristina et al., 2019). Diburukkan lagi oleh keadaan yang melibatkan kekurangan kelengkapan peralatan dan lain-lain kemudahan yang tidak diberi perhatian oleh pihak sekolah. Kesedaran murid terhadap kepentingan aktiviti kokurikulum hanya disebabkan oleh faktor minat dan rakan-rakan sebaya sahaja. Hasil kajian turut disokong oleh Mohd Jaflus (2008) mendapati bahawa faktor utama penghalang penglibatan murid dalam aktiviti sukan adalah faktor kemudahan.

\section{Penghargaan (Acknowledgement)}

Terima kasih kepada pihak Sekolah Kebangsaan Tualak, Kuala Nerang, Kedah kerana telah memberi sokongan penuh dalam kajian dan memudahkan proses untuk mendapat data.

\section{Kewangan (Funding)}

Kajian dan penerbitan ini tidak menerima sebarang tajaan atau bantuan kewangan.

\section{Konflik Kepentingan (Conflict of Interests)}

Penulis tidak mempunyai konflik kepentingan dalam kajian dan penerbitan ini.

\section{Rujukan}

Akta Pendidikan 1996 (Akta 550) (1996). Kementerian Pendidikan Malaysia.

Azrina Md Azhari et al. (2017). Tahap Kecergasan Fizikal di Kalangan Pelajar Pintar dan Berbakat, E-Proceeding of the 6th Global Summit on Education 2017.

Chen, P. D., Lambert, A. D., \& Guidry, K. R. (2020). Computers \& Education Engaging online learners: The impact of Web-based learning technology on college student engagement. Computers \& Education, 54(4), 1222-1232. https://doi.org/10.1016/j.compedu.2009.11.008.

Chua, Y. P. (2011). Kaedah dan statistik penyelidikan: kaedah penyelidikan. Mcgraw-Hill Education

Corbin, C. B. \& Lindsey, R. (2006). Fitness for Life. Human Kinetics. https://www.humankinetics.com/AcuCustom/Sitename/K12DAM/5f99c15c3dbe-4b58-baad-74dd90d2044e/9780736085717.pdf

Corbin, C. B., Lindsey, R., Welk, G. J., \& Corbin, W. R. (2002). Concepts of Fitness and Wellness: A Comprehensive Lifestyle Approach, 4th edition. St. Louis: McGraw-Hill.

Cristina, A. et al. (2019). Minat Murid dalam Pembelajaran Sekolah Rendah. Jurnal Pendidikan Malaysia. Putrajaya.

Doherty, J. \& Brennan, P. (2007). Physical Education and Development: A Guide for Teachers. Routledge 
Faigenbaum, A. D., \& Mediate, P. (2016). Effects of Medicine Ball Training on Fitness Performance of High-School Physical Education Students. The Physical Educatior, 160-167.

Hill, G. M., Randle, K., \& Mullen, S. (1992). Fitness strategies in high school physical education programs. Physical Educator, 49(4), 195-205.

Khedri, M., Chan, S. H., \& Helen, T. (2015) Interpersonal-drivan Features in Research Articel Abstract: Cross- disciplinary Metadiscoursal Perspective. Pertanika Journal of Social Sciences \& Humanities, 23(2), 303-314.

Liza Mohd Alias, Mohd Radzani Abdul Razak \& Erwan Ismail (2020). Tahap Kecergasan Fizikal Dalam Kalangan Murid Sekolah Menengah Rendah Di Kawasan Tangga Batu, Melaka. Fakulti Pendidikan, Universiti Kebangsaan Malaysia, Malaysia.

Manchelah, N. (2017) Keberkesanan perkhidmatan bimbingan dan kaunseling sekolah menengah di Malaysia / Manchelah Natesan. PhD thesis, University of Malaya.

Md Suhaimi Elias et al. (2018). Multivariate analysis for source identification of pollution in sediment of Linggi River, Malaysia. Environmental monitoring and assessment, 190(4), 1-16.

Mohammad Sari. N \& Esa. A Factors Affecting Students Participation in Extra-curricular. Elixir Psychology, 107, 46960-46962

Mohd Jaflus Bahari. (2008). Faktor-faktor yang menghalang penglibatan pelajar dalam kegiatan kokurikulum sukan di kalangan pelajar sekolah menengah kebangsaan daerah Seremban. http://www.ipislam.edu.my/uploaded/file/jaflus.pdf [18 Januari 2011]

Mohd Tarmizi Azeman \& Mohd Radzani Abd Razak (2019). Sumbangan Kokurikulum dan Pendidikan Jasmani Terhadap Kecergasan Fizikal Pelajar, 663-6701. https://123dok.com/document/zw101x1q-sumbangan-kokurikulum-pendidikanjasmani-terhadap-kecergasan-fizikal-pelajar.html

Mok, S. S. (2008). Murid dan Alam Belajar, Siri Pengajian Profesional. Perak: Penerbitan Multimedia Sdn. Bhd.

Nor Suhara \& Jamil Ahmad (2010), Kepentingan Kokurikulum dalam Pendidikan Di Sekolah Menengah, Proceedings of The 4th International Conference on Teacher Education; Join Conference UPI \& UPSI Bandung, Indonesia, 8-10 November 2010.

Ong, S. L. et al. (2021). Persepsi guru pendidikan jasmani dan kesihatan terhadap mata pelajaran PJK - Kajian Secara Kualitatif. Researchgate. https://www.researchgate.net/publication/349238548_Persepsi_guru_pj_terhada p_pjk_kualitatif

Peraturan-Peraturan Pendidikan (Persatuan Sekolah ) (1998).

Saharia Ismail (2015). Pembangunan Insan dalam Falsafah Pendidikan Kebangsaan. Journal of Human Capital Development, 8(2), 83-99.

Sekaran, U. \& Bougie, R. (2013) Research Methods for Business: A Skill-Building Approach. 6th Edition. Wiley, New York.

Wan Azlan Wan Ismail \& Tajul Ariffin Muhamad (2019). Pendidikan Jasmani di Malaysia: Motif Halangan dan Komitmen. Penerbit Universiti Kebangsaan Malaysia (UKM).

Wiersma, W. (1995). Research methods in education: An introduction. Boston: Allyn \& Bacon.

World Health Organization, WHO (2010). Global recommendations on physical activity for health. World Health Organization

Wuest, D. A., \& Bucher, C. A. (2001). Foundations of Physical Education and Sport. McgrawHill College.

Zulkifli, H. \& Norazilawati, A. 2016. Penilaian Guru Sekolah Rendah Di Daerah Kinta Utara Terhadap Pentaksiran Aktiviti Jasmani, Sukan Dan Kokurikulum (PAJSK). JPBU Edisi Khas, 18-24. 